\title{
YOUTH UNEMPLOYMENT IN EUROPE - BUSINESS CYCLES, CRISES, AND POLICY RESPONSES
}

\author{
Albena Vutsova ${ }^{1}$, Martina Arabadzhieva ${ }^{2}$, Todor Yalamov ${ }^{3}$
}

\begin{abstract}
:
Purpose: The goal of the paper is to analyse in which countries' youth unemployment is statistically pro or countercyclical and how crises in the last decade have affected it. What would the plausible explanations for diverging patterns within the EU and other European countries be? In what terms is the young people's labour market across Europe imbalanced?

Methodology: The paper builds on Gontkovicova et al.'s (2015) analysis of correlations between GDP growth and youth unemployment on an annual basis by adding more indicators and considering the quarterly basis as well. The quantitative approach is enriched by qualitative insights on Southeast European countries studied within the Erasmus+ YouthCap project (CRA, 2020)

Findings: Most of the countercyclical youth unemployment trends in the last 20 years are observed in Eastern European countries (Bulgaria, Hungary, Poland and Slovenia). From Western European countries Iceland, Denmark and Portugal are countercyclical. The most resilient countries in terms of COVID-19 are North Macedonia, Serbia, Turkey and Iceland, which were able to reduce youth unemployment during the coronavirus crisis (Q3 in 2019 and 2020). Plausible policy reactions have been identified based on the concept of learning societies and the need for continuous education.

Practical implications: The paper argues why localised policy responses could be more effective than a centralised solution. However, increased coordination and standardisation of secondary and higher education could lead to increased youth labour migration.

Originality/value: The paper combines a more traditional quantitative approach to the most recent data series with the qualitative approach of identifying various micro-trends by looking at selected outlier countries.
\end{abstract}

JEL Classification Numbers: J64, J68, DOI: https://doi.org/10.12955/peb.v2.263

Keywords: Public policy; Labour market; Youth unemployment; GDP

\section{Introduction}

Youth unemployment has been and continues to be a topic of significant interest in Europe. The issue became the focus of political actions after 2008 (Marconi et al., 2016) when youth unemployment reached high levels affecting not only young people but imposing additional costs to states, which resulted in decreased revenues (Grinevica and Rivza, 2018). Many authors have studied and analysed the process (Klimko and Rievajova, 2018; Bal-Domanska and Sobczak, 2019; O’Reilly et al., 2015; Banerji et al., 2014; Pastore, 2018).

A continuing trend for the labour market in Europe is that youth unemployment rates are considerably higher than the corresponding rates for adult employment - the percentage of young people who are not employed in the EU-27 is $21.8 \%$ for $2011,21.8 \%$ for 2015 and $15.1 \%$ for 2019 . For the other part of the labour force these numbers are as follows $-8.6 \%$ for $2011,8.9 \%$ for 2015 and $5.9 \%$ for 2019 . It is important to study the impact of macroeconomic factors on youth unemployment levels in order to increase the knowledge about what actions would be effective for the purpose of improving the situation in the labour market.

The aim of the article is to address the following questions: 1. Is youth unemployment pro or countercyclical and how have crises in the last decade affected it? 2. In what terms is the young people's labour market across Europe imbalanced? 3. What would the plausible explanations for diverging patterns within the EU and other European countries be?

\section{Youth labour market}

There are various reasons causing youth unemployment. On the one hand, economic factors are key as under unfavourable economic conditions young people are most likely to suffer from fewer work opportunities, are more easily dismissed from their current position and are more often offered temporary contracts (European Commission, 2013). A study conducted by the EU (Eurofound, 2020) shows that the most vulnerable part of the working force during the pandemic is again, young workers. On the other hand, there are social determinants, as well as local and regional trends, which affect young people who want to work. Several authors find that a lack of education or a lack of proper training,

\footnotetext{
${ }^{1}$ Sofia University "St. Kliment Ohridski", Sofia, Bulgaria, avutsova@yahoo.com

${ }^{2}$ Sofia University "St. Kliment Ohridski", Sofia, Bulgaria, m.srebkova@gmail.com

${ }^{3}$ Sofia University "St. Kliment Ohridski", Sofia, Bulgaria, yalamov@feb.uni-sofia.bg
} 
insufficient work experience, more flexible contract arrangements and general skill mismatch make youths unprepared for entering the labour market (Scarpetta et al., 2010; Bell and Blanchflower, 2011; Eichhorst, Hinte and Rinne, 2013). Transitions, the fast reshaping of the economic environment and changes in training, education marketisation and limited access to it have an additional impact as well. The general level of education and the education of young people are markers of the commitment to a knowledge-intensive economy and are of key importance for the improvement of the labour market (Bal-Domanska \& Sobczak, 2019).

We observed four different trajectories of youth unemployment over the last 20 years $(2000-2020)$ increase in its rates both in the first and second decades (I quadrant of Figure 1), decrease in the first decade and increase in the second (II quadrant), decrease in the two decades (III quadrant) and initial increase, followed by a decrease in the second decade (IV quadrant). Most of the EU27 countries, along with the US and Switzerland, at first marked an increase in youth unemployment before the global financial crisis (2007-2009), and later there was a decrease in unemployment (before the global COVID19 crisis). A small group, predominately Eastern European countries (Bulgaria, Poland, Slovakia, Croatia and the Czech Republic and with Finland and Sweden) observed a continuing decrease before and after the financial crisis. The youth unemployment rates in Cyprus and Turkey increased during the entire 20-year period, and Greece, Italy and Norway at first marked an improvement in terms of youth unemployment, but this trend deteriorated post-2019.

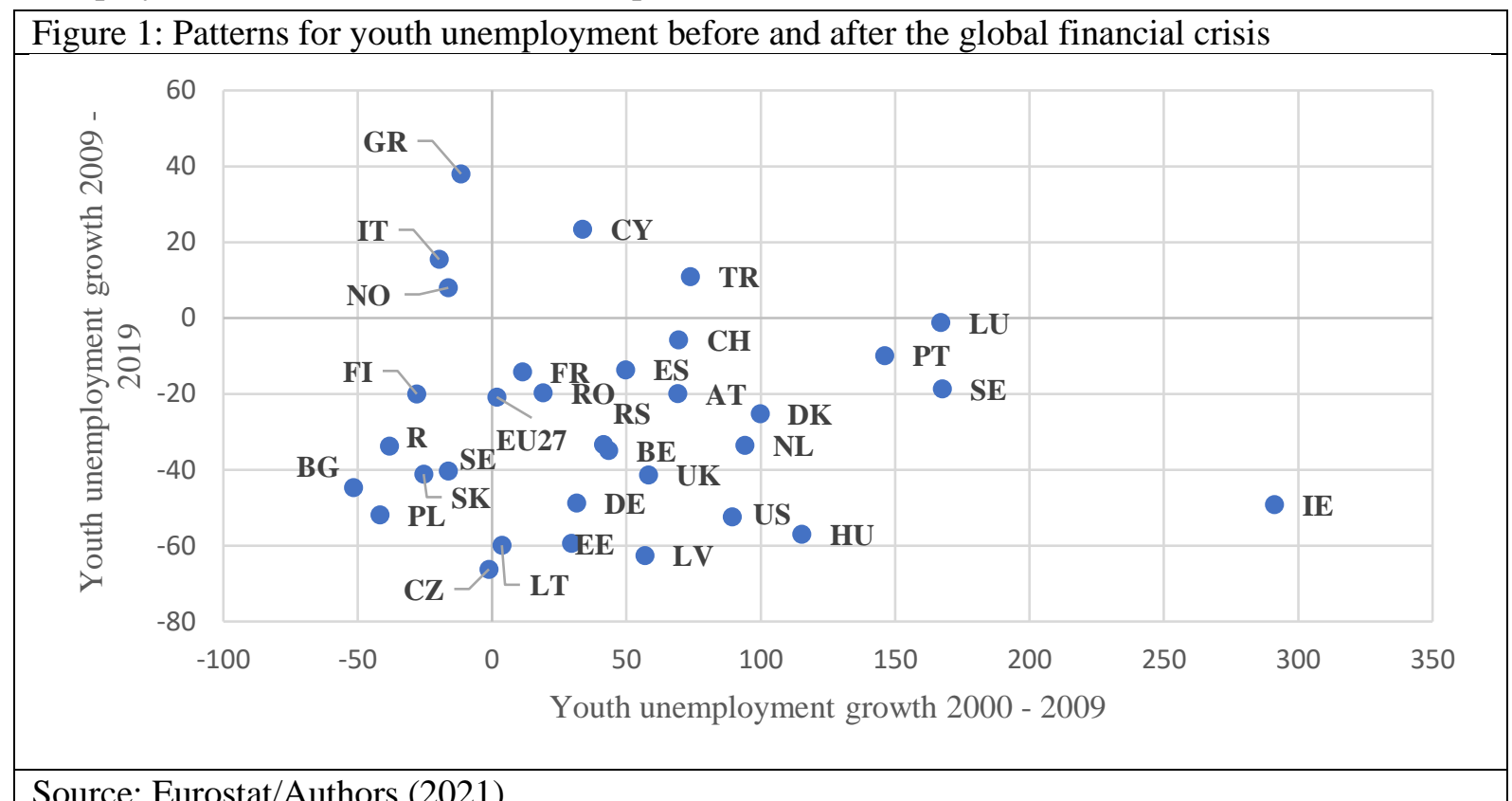

Source: Eurostat/Authors (2021)

The highest unemployment rates (around and above 30\% for 2019) for young people without work between the age of 15 and 24 in recent years are observed in North Macedonia, Greece, Italy, and Spain, which continued to top the ranking during the COVID-19 crisis in 2020 as well. In the context of geographical location, these trends correspond to similar economic community tendencies. In comparison, the lowest levels around and below 8\% for 2019 are typical for Germany, the Netherlands (developed innovative states), and the Czech Republic (moderate innovator). The imbalance across Europe is visible as the range between these levels is substantial. Bulgaria and Poland marked the most sustainable improvement in youth unemployment across the last 20 years.

Youths are considered the most vulnerable group for labour market exclusion as they enter the workforce for the first time and do not have sufficient working experience (Gontkovičová et al., 2015). In addition, their education and training are often not adequate to prepare them fully for the transition from education to work. In many states, the education market usually reacts too slowly to changes in labour market requirements. What is more, in some cases, the reforms implemented are not adequate enough to address the issue properly. Nevertheless, the transition to a knowledge-intensive economy affects youth in a positive way (Bal-Domanska \& Sobczak, 2019), which could contribute to reversing the negative trends. 
Another aspect is associated with youth migration. Some studies show that youngsters are more likely to immigrate to countries with growing GDP (Franc et al., 2019). This trend is a consequence of one of the fundamental EU principles - the free movement of persons. Despite some negative connotations for a small proportion of individuals, it is seen as a positive trend because it could decrease the overall youth unemployment rate in Europe (O'Reilly et al., 2015). However, due to the COVID-19 crisis, opportunities for migrant workers, which affects again largely youngsters, have been restricted to a great extent.

According to a survey conducted by the European Commission, young women are most likely to suffer the consequences of the COVID-19 situation (Eurofound, 2020). Usually, women are considered to be in a more unfavourable position in the labour market, but the current situation deepened this trend.

An interesting point is that some countries managed to decrease the percentage of unemployed young people during the crisis, namely the period between the last quarter of 2019 and 2020. These states are North Macedonia, Serbia, Turkey and Iceland. This might be due to the fact that, with the exception of Turkey, all other countries are small and also because targeted measures against unemployment have been implemented by them.

\section{Business cycles and their influence on the youth labour market}

Since Okun's (1962) study, when the first empirical confirmation of the negative relationship between the unemployment rate and economic growth was published, many different studies followed up to understand the differences appearing in younger and older groups of people. Some studies argue there is no statistical correlation between unemployment and economic growth (Mura et al., 2020).

O'Higgins (2001) states that the main reason for youth unemployment is namely the poor macroeconomic performance. Some authors prove that it is more volatile over time and more responsive to business cycles compared to adult unemployment rates (Dietrich, 2012; Gontkovičová et al., 2015). Variations in business cycles influence differently (less) the older and more experienced workforce (Blázquez-Fernández et al., 2018). Low GDP growth, along with other factors, is seen as a prerequisite for high levels of youth unemployment (Marques \& Hörisch, 2020). In addition, the authors claim that it was most difficult for the countries hit hardest by the financial crisis to cope with these rising rates. Authors also analyse if low levels of unemployment (lower than the natural rate of unemployment) can lead to increased wages and employee benefits (Hedvicakova et al., 2018).

Many studies look into the role of institutions in the interplay between youth unemployment and business cycles. Ayllon and Ramos (2019) explore the role of stringent employment protection legislation and higher unemployment benefits and find out that they lead to lower earnings and relatively higher labour market volatility. Tomic (2018) analyses deterrent factors for youth unemployment such as reduced mobility (high opportunity costs to change homes or to move out from parents), high levels of remittances and other social factors that could explain the differences between countries with similar economic performance. Hutengs and Stadtmann (2014) find out that male unemployment in Scandinavian countries reacts stronger to business cycles.

Other studies (Miyamoto et al., 2020) go further to analyse what active labour market policies could reduce long-term unemployment. These appear to be trainings and start-up incentives. Successful policy responses to youth unemployment should include various measures as promoting apprenticeship contracts (which will help gain experience and skills but also lower the transaction costs of getting the first labour contract), diversification of educational choices and extending the stay in education (Scarpetta et al., 2010).

Looking into the fluctuation of unemployment rates, it is critical to note the influence of the COVID-19 pandemic. It disrupted all aspects of the global economy as well as the labour market (European Commission, 2020), which was consequently reflected by the unemployment levels across Europe. At the same time, differences in the economic situation of individual states lead to dissimilar developments in the labour market (Cedefop, 2021), and there are significant variations between European countries (O’Higgins, 2015). According to Georgiou (2021), countries in South Europe suffered more from an increase in unemployment.

Previous research contributes to the view that crisis affects unalike economic structures and labour markets in a different way (Eichhorst et al., 2010). Moreover, youth unemployment has been severely 
aggravated after the recent global financial crisis (Dietrich, 2016; Marques \& Hörisch, 2019), which implies that the current COVID crisis will again have a more intense impact on youths.

\section{Methods}

In order to achieve this goal, the paper builds on Gontkovicova et al.'s (2015) analysis of correlations between GDP growth and youth unemployment on an annual basis by adding more indicators and considering the quarterly basis as well. The quantitative approach is enriched by qualitative insights on Southeast European countries studied within the Erasmus+ YouthCap project (CRA, 2020). Annual and quarterly data provided by Eurostat was monitored and treated in the survey. Correlations between the levels of total employment, comparisons with those of young people's employment rates and how they are affected by GDP growth rates have been analysed as well.

The paper combines a more traditional quantitative approach on the most recent data series with the qualitative approach of identifying various micro-trends by looking at selected outlier countries. In addition, elements of the ontology approach have been applied from a historical and contextual perspective.

Results

The following figure illustrates the correlations between GDP growth and youth unemployment for the 2010 - 2020 period.

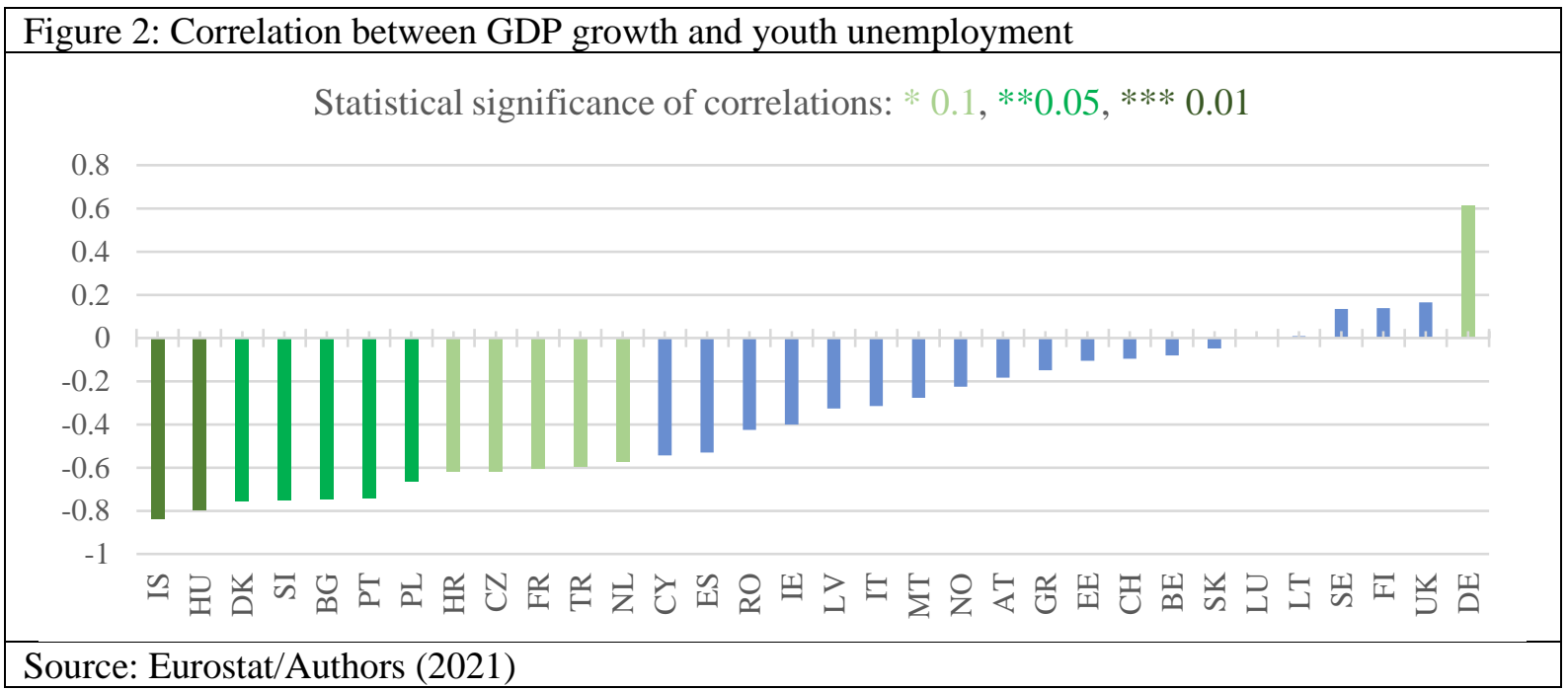

Youth unemployment is strongly countercyclical in Iceland and Hungary (correlation coefficient $r=-$ 0.80 and significance level sig= 0.01), moderately countercyclical in Denmark, Slovenia, Bulgaria, Portugal and Poland ( $\mathrm{r}$ between -0.66 and -.079 and sig=0.05) and weakly countercyclical in Croatia, the Czech Republic, France, Turkey and the Netherlands ( $\mathrm{r}$ between -0.57 and -0.62 and sig=0.10) and surprisingly procyclical in Germany $(\mathrm{r}=0.61$, sig.=0.10). Partially, this fact might be due to the high unemployment benefits, which reduce the incentives for people to seek or accept job offers, which lead to higher unemployment (Banerji et al., 2014). Moreover, the increased taxes and withdrawn incometested benefits add to this effect.

The study looks further into the relation between GDP and unemployment rates, analysing it on a quarterly basis. Again, we could see an even stronger correlation between GDP level and youth unemployment. In most cases, this relation is preserved for adult unemployment and overall unemployment rates, again proving that GDP as a macroeconomic factor influences the number of people left out of the labour force. The exceptions are several countries like France, Austria and Italy.

An interesting fact is that this correlation is observed between youth unemployment rates and GDP growth on an annual basis and GDP on a quarterly basis, but not between youth unemployment levels and quarterly GDP growth. One conceivable factor could be the uneven migration of young people between European countries and, in addition, the visible different absorption capacity of the various national sectors during different quarters, with the internal dynamic sector development being dependant on global economic changes as well. Another reason for this phenomenon might be the time lag needed for young people to respond to the demand in the labour market. 


\begin{tabular}{|c|c|c|c|c|c|c|}
\hline \multirow{2}{*}{$\begin{array}{c}\text { Age } \\
\text { Country }\end{array}$} & \multicolumn{2}{|c|}{ Between $15-25$} & \multicolumn{2}{|c|}{ Between $25-74$} & \multicolumn{2}{|c|}{ Between $15-74$} \\
\hline & Correlation & $\begin{array}{c}\text { Significance } \\
\text { level }\end{array}$ & Correlation & $\begin{array}{c}\text { Significance } \\
\text { level }\end{array}$ & Correlation & $\begin{array}{c}\text { Significance } \\
\text { level }\end{array}$ \\
\hline Czechia & -0.97 & 0 & -0.98 & 0 & -0.98 & 0 \\
\hline Slovakia & -0.96 & 0 & -0.94 & 0 & -0.95 & 0 \\
\hline Poland & -0.96 & 0 & -0.96 & 0 & -0.96 & 0 \\
\hline Ireland & -0.94 & 0 & -0.97 & 0 & -0.97 & 0 \\
\hline Bulgaria & -0.93 & 0 & -0.95 & 0 & -0.96 & 0 \\
\hline Germany & -0.92 & 0 & -0.92 & 0 & -0.92 & 0 \\
\hline Latvia & -0.92 & 0 & -0.96 & 0 & -0.96 & 0 \\
\hline Denmark & -0.91 & 0 & -0.94 & 0 & -0.95 & 0 \\
\hline Hungary & -0.90 & 0 & -0.93 & 0 & -0.93 & 0 \\
\hline Serbia & -0.89 & 0 & -0.87 & 0 & -0.88 & 0 \\
\hline Romania & -0.88 & 0 & -0.93 & 0 & -0.95 & 0 \\
\hline Slovenia & -0.88 & 0 & -0.89 & 0 & -0.91 & 0 \\
\hline Netherlands & -0.87 & 0 & -0.67 & 0 & -0.73 & 0 \\
\hline EU - 27 countries & -0.87 & 0 & -0.81 & 0 & -0.83 & 0 \\
\hline Croatia & -0.86 & 0 & -0.81 & 0 & -0.83 & 0 \\
\hline Cyprus & -0.86 & 0 & -0.82 & 0 & -0.85 & 0 \\
\hline Lithuania & -0.85 & 0 & -0.93 & 0 & -0.92 & 0 \\
\hline Malta & -0.84 & 0 & -0.93 & 0 & -0.97 & 0 \\
\hline Portugal & -0.84 & 0 & -0.78 & 0 & -0.79 & 0 \\
\hline United Kingdom & -0.82 & 0 & -0.80 & 0 & -0.81 & 0 \\
\hline Spain & -0.82 & 0 & -0.78 & 0 & -0.79 & 0 \\
\hline Sweden & -0.74 & 0 & -0.54 & 0 & -0.77 & 0 \\
\hline Estonia & -0.71 & 0 & -0.84 & 0 & -0.84 & 0 \\
\hline Finland & -0.63 & 0 & -0.51 & 0 & -0.60 & 0 \\
\hline Belgium & -0.56 & 0 & -0.49 & 0 & -0.55 & 0 \\
\hline France & -0.47 & 0 & -0.06 & 0.72 & -0.18 & 0.26 \\
\hline Greece & -0.37 & 0.02 & -0.62 & 0 & -0.58 & 0 \\
\hline Italy & -0.28 & 0.08 & -0.21 & 0.19 & -0.22 & 0.17 \\
\hline Austria & -0.23 & 0.15 & -0.06 & 0.71 & -0.16 & 0.32 \\
\hline Luxembourg & -0.18 & 0.25 & 0.42 & 0.01 & 0.43 & 0 \\
\hline Switzerland & -0.02 & 0.9 & 0.24 & 0.12 & 0.09 & 0.56 \\
\hline Norway & 0.55 & 0 & 0.53 & 0 & 0.53 & 0 \\
\hline
\end{tabular}

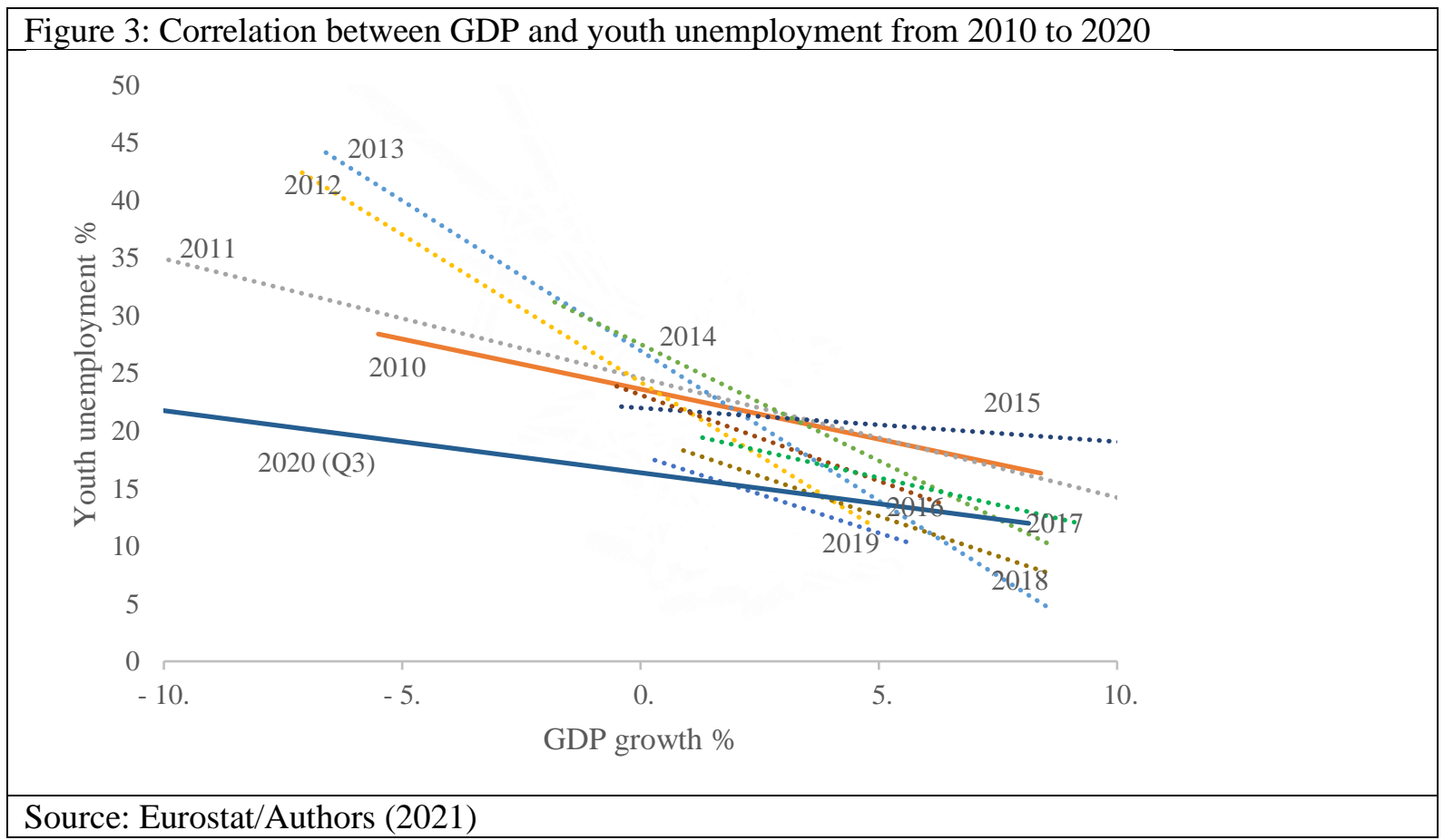


Analysing the connection between business cycles and youth unemployment at two points in time provides a clear answer to the first research question - youth unemployment is sensitive to GDP growth. The sensitivity, however, is much higher in non-crisis periods, while during crises, the effect is milder. For instance, the slopes of the trendlines (Figure 3) are flatter during 2010 (closest to the global financial crisis), 2015 (the year of the migration crisis in Europe as well as the Greek sovereign debt crisis) and 2020 (the coronavirus crisis).

In 2010 there was a significantly higher youth unemployment rate, largely due to the massive and longterm economic crisis during this period. In 2019 youth unemployment marked lower rates, and the GDP growth is relatively steady due to the economic sustainability, fast-developing innovative branches, the increase of business process outsourcing activities and thus the engagement of young and educated people with a relatively low salary rate. The last one is the catalyst for a rise in employment.

Several observations are made in relation to the second research question considering imbalances in youth labour markets. Most of the countercyclical youth unemployment is found in Eastern European countries (Bulgaria, Hungary, Poland, Slovenia, Montenegro and Serbia). These are either new member states, candidates or non-EU countries which are associated with slower economic development. In such economies, GDP growth levels are usually higher due to the low starting point.

A comparison of the (negative) correlation between youth unemployment and GDP growth based on annual and quarterly data showed a difference - while in the first case, a correlation for many countries is evident, in the second case, results are not identical. Conceivable reasons for this might be the varying migration flows of young people in respect to the time period and volume, as well as the different specificities and demands of various sectors at the time (this factor is influenced by global economic fluctuations).

The most resilient countries in terms of Covid-19 are North Macedonia, Serbia, Turkey and Iceland, which were able to reduce youth unemployment during the coronavirus crisis (Q3 in 2019 and 2020).

In times of crisis, the governments should change the policy responses to youth unemployment as it becomes less sensitive to business cycles.

\section{Discussion}

The question of what could be plausible explanations for the diverging patterns in different European countries remain. According to Ayllon and Ramos (2019), in order to address labour market variations, different policy measures are needed in different European countries, and one policy cannot fit all. This is the opinion held by other authors as well. Tomic (2018) acknowledges the considerable differences in youth unemployment rates across European countries as well as the differences in economic and noneconomic factors which influence them. She also states that one policy cannot be a universal answer.

The group in which youth unemployment rates are strongly linked to business cycles includes EU countries as well as other states - Bulgaria, Hungary, Poland, Slovenia, Montenegro and Serbia. They are either relatively new member states or candidate countries. They are characterised by GDP growth above the average for the EU over recent years but still do not represent developed economies. Most of the unemployed youths in these countries are with a low level of education and are part of different minority groups (CRA, 2020). An emblematic example is the fact that only $8.1 \%$ of young people with primary or lower education have been employed in 2019 (CRA, 2020). Among the non-economic factors, we should mention specific parental attitudes (especially among minority groups) that girls don't need to attend school. Anecdotal evidence from communities that employ both parents shows that their children attend school and thus have higher chances to stay in the education longer. One potential explanation for the statistical correlation is that economic growth in Eastern Europe creates more opportunities for unskilled workers. Partially this is due to significantly lower minimum wages in these countries, compared to the Western European countries.

The tendency to link between youth unemployment and school dropouts is widely spread in other countries. The European Commission is aiming to improve education attainment levels and access as a direct measure to reduce youth unemployment. Indirectly this could be achieved through supporting more flexible work suitable for parents and the wider availability of kindergartens.

All countries concerned represent modest or moderate innovators, which means that they react relatively slowly to digital transformation and cannot keep up with the tendencies and demands of Industry 4.0. 
As a result, the respective governments could not provide new workplaces suitable for young people. With some exceptions from the moderate innovators' group, most countries rely on outsourcing which is not considered as a guarantee for stable and long-term employment. In addition, the applied measures are short-term and unsustainable, generating cycling youth unemployment.

Pastore (2018) claims that the levels of support that different countries provide to young workers explain the differences in youth labour markets. He suggests that reforms help reduce institutional differences across countries as youth unemployment is dependent on various factors like the educational system and employment security. In this regard, increased coordination and standardisation of secondary and higher education could lead to improvement and, as a consequence, increased youth labour migration.

Also, some authors (Gjorgjievska, 2020) see opportunities in countries in Eastern Europe to use new public management as a tool to support creating workplaces, reduce unemployment, overall and youth, and the "brain drain", which is considered typical for the region. Although traditionally labelled as a 'brain drain' and a negative phenomenon for the donor country, the new knowledge workplaces provide more room for short-term migration and could also improve the levels of entrepreneurship. The latter would have positive outcomes for young people in terms of improved preparation for the next job in the local labour market. Anecdotal evidence of temporary labour migrations suggests that unemployed home workers gain working experience abroad and, upon their return, are more ready to be included in the labour market. In addition, Europe leads targeted horizontal policy towards decreasing negative trends in labour markets.

\section{Conclusion}

It is evident that the youth labour market is highly imbalanced across Europe. The levels of unemployment differ dramatically within and outside the EU. It is countercyclical in some countries and procyclical in Germany, while there is no strong evidence for any connection in the majority of countries. A plausible explanation for the diverging trends in the EU is the global flow of skilful youth work from West to East and the unskilful migration of youth from East to West. Sovereign debt crises in the South scaled up the problem with youth unemployment.

The strongest correlation between business cycles and youth unemployment is observed mainly in Eastern European countries with rapidly developing economies where the fast-growing sectors attract predominantly young people. In addition, unemployment levels are strongly connected to GDP values but not to GDP growth.

The explanations could be two - striving for a replica of some of the modern sectors of the old member states, which were obviously lacking in and respectively created conditions for attracting young and like-minded people or rapid political changes, as a result of the dynamic political milieu imposing restructuring of the economy via a top-down approach.

The study uses publicly available data and suggests useful implications which could be considered in measures addressing youth unemployment. The situation for youths entering the workforce will most likely aggravate as a consequence of the expected outcomes due to the pandemic. In this regard, it is crucial that governments undertake purposeful actions and be aware of the dynamic of youth labour markets.

Policies at a European level associated with regional reforms, especially for training and labour mobility, could help reduce youth unemployment (Banerji et al., 2014). Community measures implemented via different financial instruments should be strictly monitored and analysed and should be aimed at achieving sustainability for youth employment. What is more important, there should be continuity in this direction on a national level.

\section{Acknowledgements}

This work is supported by the SCHOLARNET project. The authors thank the anonymous referee for their valuable suggestions for the improvement of the paper.

\section{References}

Ayllon, S., Ramos, X. (2019). Youth Earnings and Labour Market Volatility in Europe. International Labour Review, 158(1), 83-113, https://doi.org/10.1111/ilr.12131

Bal-Domanska, B., Sobczak, E. (2019). Econometric Assessment of the Relation Between the Situation of Youth on the Labour Market and the Macroeconomic Factors Among the Eu Countries. Vision 2025: Education Excellence and Management of Innovations through Sustainable Economic Competitive Advantage (pp 11299-11309). 
https://depot.ceon.pl/bitstream/handle/123456789/18400/Bal-

Domanska_B_Sobczak_E_Econometric_Assessment.pdf?sequence $=1 \&$ isAllowed $=y$

Banerji, A., Saksonovs, S., Huidan Lin, H.\& Blavy, R. (2014). Youth Unemployment in Advanced Economies in Europe: Searching for Solutions Discussion Note.

International Monetary Fund. https://www.imf.org/external/pubs/ft/sdn/2014/sdn1411.pdf

Bell, D. N. F., \& Blanchflower, D. G. (2011). Young people and the Great Recession. Oxford Review of Economic Policy, 27(2), 241-267. https://doi.org/10.1093/oxrep/grr011

Blázquez-Fernández, C., Cantarero-Prieto, D., Pascual-Sáez, M. (2018). Okun's Law in Selected European Countries (20052017): An Age and Gender Analysis.Economics and Sociology, 11(2), 263-274. doi:10.14254/2071-789X.2018/11-2/18 Center for Research and Analysis (2020) Skill Gap Analysis on Capacity of Youth Organizations and Identifying knowledge required for youth professional realization, Center for Research and Analysis

Dietrich, H. \& Möller, J. (2016). Youth unemployment in Europe - business cycle and institutional effects. International Economics and Economic Policy 13, 5-25. https://doi.org/10.1007/s10368-015-0331-1

Directorate-General for Employment, Social Affairs and Inclusion. (2020). Employment and Social Developments in Europe 2020, Leaving no one behind and striving for more: Fairness and solidarity in the European social market economy. European Commission. doi: 10.2767/478772

Eichhorst, W, Escudero, V, Marx, P. (2010) The Impact of the Crisis on Employment and the Role of Labour Market Institutions. IZA Discussion Papers No. 5320. Institute for the Study of Labor (IZA). https://ssrn.com/abstract=1712627

Eichhorst, W., Hinte, H., \& Rinne, U. (2013). Youth Unemployment in Europe: What to Do about It? Intereconomics, 48 (4), 230-235, https://www.iza.org/publications/pp/65/youth-unemployment-in-europe-what-to-do-about-it

Eurofound. (2020). Living, working and COVID-19, COVID-19 series, Publications Office of the European Union. https://www.eurofound.europa.eu/sites/default/files/ef_publication/field_ef_document/ef20059en.pdf

European Centre for the Development of Vocational Training (Cedefop). (2021). Trends, Transitions and Transformation. Briefing Note. DOI: 10.2801/33991

European Commission. (2013). Labour Market Developments in Europe. Brussels, Belgium: European Commission. http://ec.europa.eu/economy_finance/publications/european_economy/2013/pdf/ee6_en.pdf

Franc, S., Časni, A. Č., \& Barišić, A. (2019). Determinants of Migration Following the EU Enlargement: A Panel Data Analysis. South East European Journal of Economics and Business, 14(2), 13-22. https://doi.org/10.2478/jeb-2019-0010 Georgiou, Miltiades N. (2021). COVID-19 on Unemployment Rate. SSRN. http://dx.doi.org/10.2139/ssrn.3801700

Gjorgjievska, E. T. (2020). The Throughput to Economic Growth in the South Eastern European Region. In Journal of Economic Boundaries and Transformation, 1(1), 54-68. https://jebtonline.com/en/article/9hv8UxwdOGzu4oyDZ1wL

Gontkovičová, B., Mihalčová, B., \& Pružinský, M. (2015). Youth Unemployment - Current Trend in the Labour Market? Procedia Economics and Finance, 23, 1680-1685. https://doi.org/10.1016/s2212-5671(15)00554-7

Grinevica, L., \& Rivza, B. (2018). Economic costs of youth unemployment in the European Union. Economic Science for Rural Development No 48, pp 299-305. https://doi.org/10.22616/esrd.2018.098

Hedvicakova, M., Sokolova, M. \& Mohelska, H. (2018). The Impact of Economic Growth on Wages and The Supply of Employee Benefits in The Czech Republic. Transformations in Business \& Economics, 17 (3), 140-154.

http://www.transformations.knf.vu.lt/45/article/thei

Hutengs, O., \& Stadtmann, G. (2014). Age- and Gender-Specific Unemployment in Scandinavian Countries: An Analysis based on Okun's Law. Comparative Economic Studies, 56(4), 567-580. https://doi.org/10.1057/ces.2014.22

Klimko, R., Rievajova, E. (2018). Youth and The Labour Markets in the European Union. In Veselica, R., Dukic, G., Hammes, K. (Eds.), Economic and Social Development, 36th International Scientific Conference on Economic and Social Development - "Building Resilient Society" (pp 330-336). Varazdin Development and Entrepreneurship Agency, Varazdin, Croatia / University North, Koprivnica, Croatia / Faculty of Management University of Warsaw, Warsaw, Poland / Faculty of Law, Economics and Social Sciences Sale - Mohammed V University in Rabat, Morocco.

http://repo.bg.pw.edu.pl/index.php/en/r\#/info/book/WUT64f72281ecf1418591bb140b244a9636/Economic+and+Social+Dev elopment+36th+International+Scientific+Conference+on+Economic+and+Social+Development+\%E2\%80\%93+\%22Buildin $\mathrm{g}+$ Resilient+Society $\% 22 \% 3 \mathrm{~B}++$ Book+of+Proceedings

Marconi, G., Beblavý, M., \& Maselli, I. (2016). Age Effects in Okun's Law with Different Indicators of Unemployment. Applied Economics Letters, 23(8), 580-583. https://doi.org/10.1080/13504851.2015.1090540

Marques, P. \& Hörisch, F. (2020). Understanding massive youth unemployment during the EU sovereign debt crisis: a configurational study. Comparative European Politics, 18, 233-255 https://doi.org/10.1057/s41295-019-00184-3

Miyamoto, H., Suphaphiphat, N., and Lee, J. (2020). Mitigating Long-term Unemployment in Europe. IMF Working Papers, 2020 (168). https://doi.org/10.5089/9781513554464.001

Mura, L., Zsigmond, T., Kovács, A. \& Baloghová, E. (2020). Unemployment and GDP Relationship Analysis in The Visegrad Four Countries. Online Journal Modelling the New Europe, 2020 (34). doi: 10.24193/OJMNE.2020.34.06

O'Higgins, N. (2001). Youth unemployment and employment policy: a global perspective. A global perspective. MPRA. http://mpra.ub.uni-muenchen.de/23698/

O'Higgins, Niall. 2015. Youth Unemployment. IZA Policy Paper No. 103, Bonn, Institute for the Study of Labor. http://ftp.iza.org/pp103.pdf 
O’Reilly, J., Eichhorst, W., Gábos, A., Hadjivassiliou, K., Lain, D., Leschke, J., Mcguinness, S., Kureková, L. M., Nazio, T., Ortlieb, R., Russell, H., \& Villa, P. (2015). Five Characteristics of Youth Unemployment in Europe. SAGE Open, 5(1), 215824401557496. https://doi.org/10.1177/2158244015574962

Okun, A.M. (1962). M, Potential GNP, its measurement and significance 1962, Cowles Foundation, Yale University.

Pastore, F. (2018). Why Is Youth Unemployment So High and Different Across Countries? IZA World of Labor. https://doi.org/10.15185/izawol.420

Scarpetta, S., A. Sonnet and T. Manfredi, 2010. Rising Youth Unemployment During the Crisis: How to Prevent Negative Long-term Consequences on a Generation? OECD Social, Employment and Migration Working Papers, No. 106, OECD Publishing, Paris, https://doi.org/10.1787/5kmh79zb2mmv-en

Tomic, I, 2018. What Drives Youth Unemployment in Europe? Economic vs Non-Economic Determinants. International Labour Review, 157(3), 379-408, https://doi.org/10.1111/ilr.12113 